\title{
Chapter 11 \\ The Capability Approach in Social Work with Older People
}

\author{
Inger Kjellberg
}

\subsection{Introduction}

In this chapter, I will focus on how the capability approach has been used in research on social work with older people. The chapter starts with a general definition of social work, and social work with older people in particular, followed by a discussion of the merits and challenges of the use of the capability approach in social work research addressing the social care of older people.

Social work is both a practice-based profession and an academic discipline, which is mainly concerned with a large range of social problems such as poverty, homelessness, drug abuse, criminality and violence against vulnerable groups. Poverty is a primary subject of research and the social deprivation associated with it is of great concern to social workers (Payne, 2005). The capability approach as conceived by the economist Amartya Sen (1999) and developed by philosopher Martha Nussbaum (2011) offers tools for a multidimensional analysis of poverty, with a broad perspective on the different constraints that can limit people's lives. The capability approach has also been developed by Ingrid Robeyns (2005, 2006, 2017). In social work research, different theories are used, for example, as a heuristic or as a framework for analysis, and the capability approach developed by Sen $(1993,1999)$ is one such theory. Sen defines the capability approach as 'an intellectual discipline that gives a central role to the evaluation of a person's achievements and freedoms in terms of her actual ability to do the different things a person has reason to value doing or being' (Sen, 2009: 16). In social work research, the capability approach can be a useful tool for exploring individuals' expectations and

\footnotetext{
I. Kjellberg $(\bowtie)$

Department of Social Work, University of Gothenburg, Gothenburg, Sweden

Centre for Ageing and Health - AgeCap, University of Gothenburg,

Gothenburg, Sweden

e-mail: inger.kjellberg@ @ocwork.gu.se
} 
their opportunities to realise those expectations in general. Sen $(1993,1999)$ argues that what people can positively achieve depends on their economic opportunities, social powers, political liberties and the enabling conditions of good health, basic education, encouragement and the cultivation of initiatives. It has been suggested that the key concepts of the capability approach are easily connected to the core of social work and that it offers directions for almost every basic social work strategy (den Braber, 2013). However, these key concepts are still said to be relatively unknown and undeveloped in social work (Babic et al., 2010).

\subsection{Social Work with Older People}

There are two main branches of social work with older people: care of older people and ageing (Jönson \& Harnett, 2015). Social workers are engaged in the care of older people in different ways and social work education has to prepare students for working within social care. However, their tasks differ between countries. In Sweden, for example, social workers conduct need assessments for home-care services, and eligibility assessments for residential care (for people aged 65 and above); they work as care managers in residential care facilities for older people, in interdisciplinary healthcare teams and with support for informal caregivers. Social workers also meet older people in other social work areas, such as homeless centres and substance abuse clinics.

The other branch of social work focuses on social problems. Older people are not a social problem in themselves, but discriminatory practices are such a problem. Thus, the second branch of social work with older people (i.e. ageing) concerns social problems associated with old age and ageism: stereotypical categorisations and assumptions about older people as a group (Andersson, 2008; Bytheway, 2005), which interfere with social work services and ethical principles within social work. Social workers are involved in the care of older people who have complex and significant support needs or where there are other social problems, such as genderbased violence, drug abuse, poverty or social deprivation. Older people are not a homogeneous group, people with all kinds of problems grow old. Categorisation by chronological age is just one way of delimiting a group of people, but it may not be because of age-related problems that older people seek the help of social workers. Most people live their lives without having to use social services, and only a minority of older people and their informal carers are in need of social work skills (Ray \& Phillips, 2012). The need for social services by older people is definitely not inevitable. However, it has been suggested that the capability approach seems to embrace the different aspects of social work with older people and that this approach offers a focus on processes and interactions that pays attention to diversity and the contextualisation of people's social constraints (Gopinath, 2018). 


\subsection{Main Concepts of the Capability Approach}

According to Ingrid Robeyns (2006: 352), the capability approach is not a theory that can explain poverty, inequality or well-being, but it is 'a normative framework for the evaluation and assessment of individual well-being and social arrangements, the design of policies, and proposals about societal change'. Social justice is also important to social work and it is defined in the Code of Ethics for social workers as well as in the definition of what social work is (The International Federation of Social Workers [IFSW], 2014). Discussions within social work have been highlighting the need for social work to develop its own theoretical basis for social justice and suggesting that the capability approach, as developed by Sen and Nussbaum, can provide a philosophical frame of justice for teaching social work (Carlson et al., 2016). Notwithstanding, Robeyns (2006) argues that the capability approach suggests complementary insights to other approaches, and does not replace other theories. The capability approach opens up an interdisciplinary space in the study of well-being, inequality, justice and public policies.

There are several essential concepts in the capability approach. Here, I will only recapitulate the main characteristics of five main concepts. Functionings are described as valuable activities, various things a person values being able to do and to be, indicating individual choices. Capabilities are the actual opportunities people have to live the life they value and to implement their choices or achieve their functionings. An older person's capabilities are dependent on the opportunities he or she has, and the abilities she or he possesses. Another concept is freedom. In order for individuals to practise their rights and to live a life that they value, they need to use their capabilities to do the things that they value. Sen (1999) distinguishes two different kinds of freedom: substantive and instrumental. The former allows individuals to participate in a democratic community, the latter concerns individual freedom to live the life you choose. Conversion factors influence individuals' freedom to achieve functioning at both a personal and an environmental level. Finally, agency is closely related to freedom and well-being. Individual agency is a person's ability to pursue the goals they have reason to value (Deneulin, 2008; Sen, 1999). An agent may exercise agency in seeking his or her own well-being, but agency may also be pursued collectively or to reach altruistic goals. Robeyns (2017) states that not all versions of the capability approach need to endorse an account of agency, although for social workers the acting agent plays a crucial role in achieving goals in human life (den Braber, 2013).

\subsection{The Capability Approach and Social Work}

Several researchers have commented on the potential of the capability approach as an alternative conceptual framework for social work that can challenge the dominance of neoliberal ideology and promote human rights and social justice 
(Banerjee \& Canda, 2012; Gupta, 2017; Reisch \& Jani, 2012). The focus of the capability framework overlaps with much of the interest in social work research, as well as in social work practice: the focus on evaluating individual levels of well-being and social institutions, policy formation and social change towards social justice. In social work, social justice is a core value of the profession, and it is defined in the Code of Ethics for Social Workers (National Association of Social Workers [NASW], 2017) as well as in the Global Definition of Social Work (IFSW, 2014). There are however competing approaches in social work research, for example different emancipatory forms of social work, which are also closely connected to the endorsement of social justice and human rights, such as empowerment (Adams, 2008) and anti-oppressive practice (Dominelli, 2002). Empowerment has been defined as 'the capacity of individuals, groups and/or communities to take control of their circumstances' (Adams, 2008: xvi) in order to maximise the quality of their lives. In correspondence with the capability approach, empowerment is also contested via differing perspectives and use (Tew, 2006); it can be used to mean individuals' ability to take control of their own lives, mutual support and collective action undertaken by marginalised groups, but it can also be defined for powerless people by professionals and politicians. Nonetheless, despite the similarities in rhetoric between certain forms of emancipatory social work and the capability approach, there are also differences. In antioppressive research, power relations that influence research projects have been scrutinised, encouraging critical reflexivity on the processes of power in social work research (Rogers, 2012; Strier, 2007). In anti-oppressive social work practice, social justice and human development are promoted by developing empowering forms of practice. Anti-oppressive practice is concerned with 'personal, institutional, cultural and economic issues and examines how these impinge on individuals' behaviour and opportunities to develop their full potential as persons living within collective entities' (Dominelli, 2002: 36).

Neither power relations nor anti-oppressive strategies for researching marginalised groups are particularly pronounced in the capability approach. Although there are obvious connections between the capability approach and social work, questions about whether it is sufficiently critical of social power, oppression and global injustices have been raised (Carlson et al., 2016; Dean, 2009; Deneulin, 2008). Critical social work has both a narrow and a broad definition (Gray \& Webb, 2009). In the narrow sense, structural analyses of the aspects of society that are oppressive, unjust and exploitative are connected to the various circumstances experienced by social workers and service users. Such analyses often have their starting point in theories aimed at a structural level, identifying political domination, as in for example feminism, race theory and Marxism. The broad sense of critical social work is more concerned with developing 'best practice' agendas where the critical dimension is regarded as a disposition of the social workers and their capacity to reformulate or challenge existing practices (Gray \& Webb, 2009).

What critical social work is, and can be, is an ongoing debate within social work, which highlights the question of what social work really is (Hugman, 2010; Olson, 
2007; Payne, 2005). Olson (2007) defines social work as two distinct projects: the social justice project, which seeks to transform the conditions of human suffering, and the professional project, with its focus on achieving legitimacy within a competitive professional system. Olson argues that these two projects have different assumptions, missions and goals; however, they are conflated in social work's understanding of itself and what it does. Olson also concludes that it is the social justice project that loses out in this conflation.

Social work has also been distinguished in micro- and macro-level approaches (Hugman, 2010). The micro-level approach is concerned with individual functioning and questions of social order. Historically, the micro-level approach can be traced back to the emergence of the social work profession at the end of the nineteenth century, and more specifically to the Charity Organisation Societies (Hugman, 2010). This branch of social work has generally been regarded as politically conservative, and builds on a theory of charity recipients' ability to make the best use of the resources given to them. The macro-level perspective is based on a structural understanding of social problems whereby social change is pursued. This has been regarded as a politically radical view (Hugman, 2010; Olson, 2007). The emergence of the macro-level aspect of social work has its roots in the Settlement movement, in which well-educated and wealthy people moved to poor areas to live and work (Payne, 2005). The theory behind this movement was that the wealthy class possessed social resources that spread outward to the whole community, and thus everybody living in the area would then develop capacities to improve their own lives and resolve social problems (Hugman, 2010).

\subsection{Methodological Framework}

There is no comprehensive review of the literature on how the capability approach is used in social work research. Research findings relevant to social work professionals and researchers can be found in many journals from different disciplines. In order to understand how the capability approach has actually been used in social work research, a scoping review was conducted (Kjellberg \& Jansson, 2020). A scoping review shares some similarities with systematic reviews, such as the use of rigorous and transparent methods to identify and analyse relevant literature regarding a well-defined topic. Scoping reviews are used when the topic has not yet been extensively reviewed and where a potentially large body of literature is available, which includes different study designs and methodologies (Pham et al., 2014). In contrast, systematic reviews often synthesise evidence from randomised controlled trials, summing up the best available research. Our scoping review followed the framework outlined by Arksey and O'Malley (2005) and used the PRISMA checklist and flow chart for scoping reviews (Tricco et al., 2018). The focus of the review was to identify and analyse how the capability approach is used in social work research, including research employing a range of different methods, and not to critically evaluate the research for best practice, as would 
have been the focus in a systematic review. After a two-step screening, 17 articles were included in the analysis (Kjellberg \& Jansson, 2020). Only three of these articles addressed social work with older people (Horrell et al., 2015; Tanner et al., 2018; Yeung \& Breheny, 2016). For the specific purposes of this chapter, the search terms were expanded to 'gerontological social work', older people and social work using three databases (Proquest Social Service, Web of Science, Scopus), the timeframe ranging from 1 January 2000 to 20 February 2018. The inclusion criteria were: (1) the capability approach was a main part of the research process, (2) the article contained empirical research specifically addressing social work with older people, and (3) social work theory or practice was explicitly addressed. The exclusion criteria were: (1) capabilities were not connected to the capability approach as outlined by Sen or Nussbaum, (2) no empirical material was presented (e.g., some of the articles contained theoretical discussions and no identified research population or method), and (3) the article did not address social work research with older people. Articles using the capability approach in research about older people amongst other professions (e.g. nursing) were also excluded. Only one more article was found that presented primary research using the capability approach with a focus on older people, in comparison with the scoping review (Kjellberg \& Jansson, 2020). The selected studies were limited to English-language, peer-reviewed journals accessible from Gothenburg University Library. In all, four articles are discussed in this chapter; three studies were identified in the scoping review and one more in the extended search.

In the four studies discussed below, the research methods and findings are identified, the use of the capability approach is specified and the extent to which this approach is presented as valuable to social work with older people is considered. A scoping review is not a comprehensive evaluative method of research quality. The questions guiding the presentation and discussion of the studies are: in what way is the capability approach used in the analysis of the empirical material: What applications, merits and challenges are discussed? To what extent is the capability approach acknowledged (or not) as valuable for social work with older people, and with what kinds of arguments?

\subsection{Different Uses of the Capability Approach}

The uses of the capability approach in social work research were delineated into four main categories: exploring the subjective sense of well-being, addressing social inequalities at a structural level, as a tool for social workers in practice and to evaluate social work practices (Kjellberg \& Jansson, 2020). The first two categories concern the level at which the empirical material was analysed. Three of the articles explored the subjective sense of well-being, and the capability approach addressed subjective experiences at an individual level (Gilroy, 2006; Horrell et al., 2015; Yeung \& Breheny, 2016). Although three of the articles concerned well-being at an individual level, it was also claimed that it is not enough 
to be engaged with individuals and families. Critical social work also needs to be developed through engaging with the suffering of individuals in the context of political processes at the societal level. The second category includes articles mostly exploring social structures, and their influence on different groups of people. One article (Tanner et al., 2018) fell into this category. The third category deals with the specific use of the capability approach for social workers when working with people in need of support, but none of the four studies fitted this category. Finally, the fourth category has evaluative aims, where the capability approach is used as a measurement of quality of life. None of the studies fell into this category, although one article (Gilroy, 2006) used a list of quality of life, but it did not have any evaluative aims.

\subsection{The Capability Approach in Social Work with Older People}

The four studies addressing social work with older people reported research findings from New Zealand (some of the same authors in two studies, but different empirical material) and the UK, using both qualitative and quantitative methodology (see Table 11.1).

Table 11.1 Description of reviewed research articles by author, year of publication, researched group, country, empirical material, and objective of the studies

\begin{tabular}{|c|c|c|c|c|c|}
\hline Author & Year & $\begin{array}{l}\text { Researched } \\
\text { group }\end{array}$ & Country & $\begin{array}{l}\text { Empirical } \\
\text { material }\end{array}$ & Objective of the study \\
\hline Gilroy & 2006 & $\begin{array}{l}\text { Older people } \\
>50\end{array}$ & UK & $\begin{array}{l}10 \text { studies from } \\
\text { growing older, } \\
\text { four audit } \\
\text { commissions }\end{array}$ & $\begin{array}{l}\text { To create a list of capabilities } \\
\text { derived from older people's } \\
\text { own voices and contribute to } \\
\text { the empowerment of older } \\
\text { people. }\end{array}$ \\
\hline $\begin{array}{l}\text { Horrell } \\
\text { et al. }\end{array}$ & 2015 & $\begin{array}{l}\text { Informal } \\
\text { caregivers for } \\
\text { older people }\end{array}$ & $\begin{array}{l}\text { New } \\
\text { Zealand }\end{array}$ & $\begin{array}{l}\text { Online forum, } 60 \\
\text { caregivers }\end{array}$ & $\begin{array}{l}\text { To create a capability list } \\
\text { specific to the values and health } \\
\text { needs of those providing } \\
\text { informal eldercare. }\end{array}$ \\
\hline $\begin{array}{l}\text { Tanner } \\
\text { et al. }\end{array}$ & 2018 & $\begin{array}{l}\text { Older people } \\
\text { (aged 70-92) } \\
\text { self-funding } \\
\text { social care }\end{array}$ & England & $\begin{array}{l}\text { Eight individual } \\
\text { semi-structured } \\
\text { interviews }\end{array}$ & $\begin{array}{l}\text { To advance understanding of } \\
\text { the experiences of older people } \\
\text { living in the community who } \\
\text { are self-funding their own } \\
\text { social care by applying the } \\
\text { capability approach (CA) to } \\
\text { these experiences. }\end{array}$ \\
\hline $\begin{array}{l}\text { Yeung } \\
\text { and } \\
\text { Breheny }\end{array}$ & 2016 & $\begin{array}{l}\text { People aged } \\
50-87\end{array}$ & $\begin{array}{l}\text { New } \\
\text { Zealand }\end{array}$ & $\begin{array}{l}\text { NZ longitudinal } \\
\text { study of ageing } \\
(\mathrm{N}=2793)\end{array}$ & $\begin{array}{l}\text { To explore the determinants of } \\
\text { subjective Well-being among } \\
\text { older people. }\end{array}$ \\
\hline
\end{tabular}




\subsubsection{Exploring the Subjective Sense of Well-being}

In a study from the UK, Gilroy (2006) worked out a list of capabilities derived from research within government-funded programmes that gave prominence to older people's own definitions of a life worth living. Gilroy's research included ten empirical studies from government-funded programmes. The objectives of these research programmes were to explore different aspects of quality of life in old age. The list followed Ingrid Robeyns' (2006) approach by listing factors of importance for quality of life as expressed by older people themselves, which included the following domains: Health, adequate income, mobility, a safe neighbourhood, a comfortable and secure home, social relations and support. The capability approach was described as appropriate for analysing how policy, societal attitudes and neglect constrain the freedom of older people. It was also suggested that the sum of all capabilities may not be expressed as freedom, as in Sen's view; instead, older people preferred the word independence. Moreover, the capability approach was highly recommended because it brought the older people's voices into focus and thus also contributed to their empowerment. This article is important for social work because it stresses social policies and support for older people with special needs.

One study from New Zealand (Horrell et al., 2015) examined the capabilities that are important for the health of informal caregivers of older people in New Zealand. The method used was an online forum in which 60 informal caregivers participated, and the material analysed was their discussion on the forum. The capability approach informed the qualitative inquiry, and in the thematic analysis Nussbaum's list of core capabilities was used. The results showed the interconnection between capabilities and emotions. The caregivers' freedom to choose how they lived their lives was to a high extent influenced by their emotional attachment to those for whom they cared. The caregivers valued the capability to care for loved ones. The core principle emphasised in this study was to identify capabilities through deliberative democracy, which inspired the methodology of online 'democratic dialogue' (ibid.). It was also asserted that the capability approach as delineated by Sen informed the choice of a participatory method and the use of thick descriptions (i.e., a detailed account of field experiences in which the researcher makes explicit the patterns of cultural and social relationships and places them in context). The capacity to experience emotions was important across all capabilities. The different capabilities were described as interconnected; for example, providing care for loved ones required giving up employment, leading to financial difficulties. This study is important for social work because informal caregiving and support for this group is a field of practice for social workers. Furthermore, social care and social policies were discussed in the article.

In another study from New Zealand, Yeung and Breheny (2016) used the capability approach to understand the determinants of subjective well-being among community-dwelling older people. A sample from the New Zealand Longitudinal Study of Ageing ( $\mathrm{n}=2793$, aged 50-87) was used to examine the relationships between commodities, environmental factors and the capabilities of older people to 
achieve well-being. A specific model of the capability approach was employed which situated 'healthy ageing as a matter of social justice and in particular, an issue of inequality' (Saleeby, 2007: 296). The characteristics of commodities were distinguished as a reflection of a person's life situation, which includes environmental and personal factors as well as physical functioning. Personal factors, for example economic well-being, disability and environmental factors such as accessibility, stigma and attitude were said to facilitate or limit functionings. Additionally, a measure of living standards for older people based on Sen's capability approach (LSCAPE) was developed and included in the survey (further described in Yeung \& Breheny, 2016, Appendix 2). This study aimed to explain the relationships between measured functionings, and the results showed that real opportunities increased well-being. For the oldest participants, the relationship between living standards and well-being was weak, but experiences of discrimination had a stronger effect on well-being. The need for policymakers and social workers to address aspects of discrimination, poor mental health and disability in older age was highlighted, issues that are of high priority for social work.

\subsubsection{Addressing Social Inequalities at a Structural Level}

Older people's experiences of self-funding social care in the UK were analysed by Tanner et al. (2018). The authors discuss both the capability approach and personalisation, arguing that these are individualised and not collective ways to conceive functionings and well-being. The authors criticise these approaches for reflecting neoliberal values, which do not sufficiently consider the influence of social structures on capabilities. By using a relational-political interpretation of the capability approach, they seek to remedy the criticism of an individual agenda and instead embrace structural factors that restrict or enhance capabilities and relationships that have an impact on well-being. The results underline networks of care, and through viewing capabilities and functionings in relational terms, older people's well-being is depicted as depending on relationships with others and not on individual purchasing power or consumer choice. This research is important for social work with older people because it addresses the complexities involved in finding, arranging and managing care, particularly for older people with multiple needs. At a general level, this research also aims to formulate more socially just policy responses to the funding of social care, which is also in line with a social work agenda.

\subsection{Discussion}

The aim of the scoping review was to examine how the use of the capability approach is linked to policies, practices and social justice approaches in social work research addressing older people. In general, most articles arguing that the capability 
approach is suitable for social work research emphasise that it is a theory that can be used to understand, and sometimes to underpin, action for social justice, human dignity and well-being, which correspond to the core principles of social work (den Braber, 2013). The history of social work, and its origins in welfare work once carried out by charity organisations or through the settlement movements, reveals two different theoretical approaches. Welfare is either something that is given to those in need, who use their individual abilities to make the best of their situation - or as functionings (knowledge, skills) that can be achieved in a democratic community where people share resources and support one another. In the best of worlds, these two different assumptions would be conflated, and it has been argued that the capability approach offers such an evaluative theoretical frame (Robeyns, 2005), which could be adopted, for example, in social work education (Carlson et al., 2016). However, Robeyns (2005) cautions against regarding the capability approach as simply a formula for interpersonal comparisons of welfare or as merely a theory of equality or social justice. She stresses that it is a broad normative framework with which it is possible to conceptualise and evaluate poverty, inequality and wellbeing. In the studies presented here, the capability approach was used as a measure of the relationship between different capabilities for older people. This resulted in general recommendations for policymakers and social workers to pay attention to discriminatory practices (Yeung \& Breheny, 2016). The approach was also used to understand the relationship between emotions and capabilities, leading to discussions relevant to support for informal caregivers (Horrell et al., 2015), and paying attention to relational factors, such as networks of care (Tanner et al., 2018). Finally, the capability approach was used as a way of promoting empowerment through the first-hand experiences of older people, with attention directed towards policymakers and social work in general (Gilroy, 2006).

The studies all referred to Sen, Nussabaum and Robeyns. Yeung and Breheny included specific questions in a nationwide survey designed in line with Sen's capability approach. Gilroy (2006) elaborated on Robeyns' approach of deriving a list of capabilities from 'democratic processes', and Horrell et al. (2015) used Nussbaum's ten core capabilities to analyse their material. None of the studies had an evaluative aim; instead, they assessed well-being for older people and provided recommendations for policy development and social work practice. As with most research findings, the question remains as to the degree to which policymakers and social workers actually read and make use of these research results.

Capabilities help people to achieve their functionings, but there can also be barriers to capability in people's environments, such as poverty (Sen, 1999). These social constraints, inequalities and discrimination are taken into account when using the capability approach, which is important in social work. The promotion of empowerment for older people through a focus on their own voices and encouragement to live lives of independence and well-being is also in line with the social work agenda. However, different anti-oppressive and critical theories and practices are already commonly used and discussed in social work (e.g. Dominelli, 2002). The empowerment movement has a long tradition in social work (e.g. Adams, 2008). It rests on the same premises as the capability approach: social justice, anti-oppressive 
actions and equality. The concept of empowerment was also used in the studies analysed in this chapter. As a matter of fact, the contradictory uses (and misuses) of empowerment in social work may carry some lessons for the future implementation of the capability approach, which now seems to be dawning upon social work. Tew (2006) cautions against the different uses of empowerment in social work, where it is defined for powerless people by professionals, and it is not uncommon for this definition of empowerment to be in line with a neoliberal discourse of everybody being responsible for their own actions, coupled with a call to dismantle welfare policies. For example, not every person is equally able to make choices, an issue that has been discussed in relation to older people's difficulties in choosing to leave a nursing home if they are dissatisfied with the care (Kjellberg, 2012). A similar critique applies to anti-oppressive practices (e.g. Wilson \& Beresford, 2000) and has also been raised towards the capability approach (Dean, 2009). However, as Robeyns (2006) states, the social influences on individual choice require complimentary theories in order to be adequately analysed. Nor is the capability approach a theory that can explain poverty or inequality. There may be a risk of overstating the social justice aspect of the capability approach because it corresponds to core principals in social work, just as empowerment attracts social work due to its emphasis on participatory power. However, the studies presented here did demonstrate a potential for the capability approach to be used in assessing older people's well-being. In the future, more studies concerning social care for older people with different, and more developed, ways of using the capability approach are likely to follow.

\subsection{Conclusions}

Promoting social justice and human rights in a global context are core values of the social work profession, and correspond with the basic principles of the capability approach. In this chapter, a sample of research discussing and using the capability approach in social work with older people has been presented. The starting point for the literature search was a scoping review of how the capability approach has been used in social work research (Kjellberg \& Jansson, 2020). This revealed four main applications of the capability approach: to explore the sense of subjective wellbeing, to address social inequalities at a structural level, as a tool for social workers in practice (e.g. to promote strength and support individuals and disadvantaged groups to realise their capabilities) and to evaluate social practices. Only four articles addressing social work with older people were found, despite the use of an extended search strategy. These four articles explored the sense of subjective wellbeing of older people or their informal caregivers and one study discussed social inequalities at a structural level.

It has been argued that there is great potential for the capability approach to be applied to social work strategies, professional work and research (den Braber, 2013; Babic et al., 2010). The care of older people is of great concern for social work 
because many social workers are engaged in this field. Only a few studies were found in this search; however, more seems to have been done within the fields of healthcare and developmental studies. Moreover, many empirical studies concern capabilities, poverty and disadvantaged groups, but many studies do not explicitly address 'social work', and therefore they were not included in this analysis. These studies may very well be of great interest for social work research and practice. Despite these limitations, our conclusion is that the capability approach has obviously attracted some interest in social work with older people and the amount of research elaborating on the capability approach in social work in general is growing. However, when it comes to social work with older people, it seems as though this development is in its infancy, and that there is a potential in the capability approach to assess older people's well-being. It is likely that further developments of different uses of the capability approach will follow.

\section{References}

Adams, R. (2008). Empowerment, participation and social work (4th ed.). Palgrave Macmillan.

Andersson, L. (2008). Ålderism [Ageism]. Studentlitteratur.

Arksey, H., \& O’Malley, L. (2005). Scoping studies: Towards a methodological framework. International Journal of Social Research Methodology, 8(1), 19-32. https://doi. org/10.1080/1364557032000119616

Babic, B., Graf, G., \& Germes Castro, O. (2010). The capability approach as a framework for the evaluation of child and youth care. European Journal of Social Work, 13(3), 409-413. https:// doi.org/10.1080/13691457.2010.519114

Banerjee, M., \& Canda, E. (2012). Comparing Rawlsian justice and the capabilities approach to justice from a spiritually sensitive social work perspective. Journal of Religion \& Spirituality in Social Work: Social Thought, 31(1-2), 9-31. https://doi.org/10.1080/15426432.2012.647874

Bytheway, B. (2005). Ageism and age categorization. Journal of Social Issues, 61(2), 361-374. https://doi.org/10.1111/j.1540-4560.2005.00410.x

Carlson, J., Nguyen, H., \& Reinardy, J. (2016). Social justice and the capabilities approach: Seeking a global blueprint for the EPAS. Journal of Social Work Education, 52(3), 269-282. https://doi.org/10.1080/10437797.2016.1174635

Dean, H. (2009). Critiquing capabilities: The distractions of a beguiling concept. Critical Social Policy, 29(2), 261-278. https://doi.org/10.1177/0261018308101629

den Braber, C. (2013). The introduction of the capability approach in social work across a neoliberal Europe. Journal of Social Intervention: Theory and Practice, 22(4), 61-77. https://doi. org/10.18352/jsi.380

Deneulin, S. (2008). Beyond individual agency and freedom: Structures of living together in the capability approach. In S. Alkire, M. Qizilbash, \& F. Comim (Eds.), The capability approach: Concepts, measures and applications (pp. 105-125). Cambridge University Press.

Dominelli, L. (2002). Anti-oppressive social work theory and practice. Palgrave Macmillan.

Gilroy, R. (2006). Taking a capabilities approach to evaluating supportive environments for older people. Applied Research in Quality of Life, 1(3), 343-356. https://doi.org/10.1007/ s11482-007-9025-3

Gopinath, M. (2018). Thinking about later life: Insights from the capability approach. Ageing International, 43(2), 254-264. https://doi.org/10.1007/s12126-018-9323-0

Gray, M., \& Webb, S. (2009). Critical social work. In M. Gray \& S. Webb (Eds.), Social work theories and methods (pp. 76-85). Sage. 
Gupta, A. (2017). Learning from others: An autoethnographic exploration of children and families: Social work, poverty and the capability approach. Qualitative Social Work, 16(4), 449-464. https://doi.org/10.1177/1473325015620946

Horrell, B., Stephens, C., Breheny, M., et al. (2015). Capability to care: Supporting the health of informal caregivers for older people. Health Psychology, 34(4), 339-348. https://doi. org/10.1037/hea0000144

Hugman, R. (2010). Understanding international social work. A critical analysis. Palgrave Macmillan.

International Federation of Social Workers/International Association of Schools of Social Work. (2014). The global definition of social work. http://ifsw.org/get-involved/global-definition-ofsocial-work/. Accessed 20 Feb 2018.

Jönson, H., \& Harnett, T. (2015). Socialt arbete med äldre [Social work with older people]. Natur och kultur.

Kjellberg, I. (2012). Klagomålshantering och lex Sarah-anmälningar i äldreomsorgen. En institutionell etnografisk studie [Complaints procedures and mandatory reporting in Swedish care of older people: An institutional ethnography]. Department of Social Work, University of Gothenburg.

Kjellberg, I., \& Jansson, B. (2020). The capability approach in social work research: A scoping review of research addressing practical social work. International Social Work. https://doi. org/10.1177/0020872819896849

National Association of Social Workers. (2017). Code of ethics of the National Association of Social Workers. National Association of Social Workers, Washington, DC.

Nussbaum, M. (2011). Creating capabilities: The human development approach. Harvard University Press.

Olson, J. (2007). Social work's professional and social justice projects: Discourses in conflict. Journal of Progressive Human Services, 18(1), 45-69. https://doi.org/10.1300/J059v18n01_04

Payne, M. (2005). The origins of social work: Continuity and change. Palgrave Macmillan.

Pham, M., Rajić, A., Greig, J., et al. (2014). A scoping review of scoping reviews: Advancing the approach and enhancing the consistency. Research Synthesis Methods, 5(4), 371-385. https:// doi.org/10.1002/jrsm.1123

Ray, M., \& Phillips, J. (2012). Social work with older people (5th ed.). Palgrave Macmillan.

Reisch, M., \& Jani, J. (2012). The new politics of social work practice: Understanding context to promote change. British Journal of Social Work, 42(6), 1132-1150. https://doi.org/10.1093/ bjsw/bcs072

Robeyns, I. (2005). The capability approach: A theoretical survey. Journal of Human Development, 6(1), 93-117. https://doi.org/10.1080/146498805200034266

Robeyns, I. (2006). The capability approach in practice. Journal of Political Philosophy, 14(3), 351-376. https://doi.org/10.1111/j.1467-9760.2006.00263.x

Robeyns, I. (2017). Wellbeing, freedom and justice: The capability approach re-examined. Open Book Publishers. https://doi.org/10.11647/OBP.0130

Rogers, J. (2012). Anti-Oppressive social work research: Reflections on power in the creation of knowledge. Social Work Education, 31(7):866-879. https://doi.org/10.1080/0261547 9.2011.602965

Saleeby, P. (2007). Applications of a capability approach to disability and the international classification of functioning, disability and health (ICF) in social work practice. Journal of Social Work in Disability \& Rehabilitation, 6(1-2), 217-232. https://doi.org/10.1300/J198v06n01_12

Sen, A. (1993). Capability and well-being. In Nussbaum, M., \& Sen, A. (Eds.) The quality of life. Clarendon Press.

Sen, A. (1999). The possibility of social choice. American Economic Review, 89(3), 349-378. https://doi.org/10.1257/aer.89.3.34

Sen, A. (2009). Capability: Reach and Limit. In Debating Global Society: Reach and Limits of the Capability Approach. Fondazione Giangiacomo Feltrinelli (pp. 15-28). 
Strier, R. (2007). Anti-oppressive research in social work: A preliminary definition. British Journal of Social Work, 37(5), 857-871. https://doi.org/10.1093/bjsw/bcl062

Tanner, D., Ward, L., \& Ray, M. (2018). Paying our own way: Application of the capability approach to explore older people's experiences of self-funding social care. Critical Social Policy, 38(2), 262-282. https://doi.org/10.1177/0261018317724344

Tew, J. (2006). Understanding power and powerlessness. Journal of Social Work, 6(1), 33-51. https://doi.org/10.1177/1468017306062222

Tricco, A. C., Lillie, E., Zarin, W., et al. (2018). PRISMA extension for scoping reviews (PRISMAScR): Checklist and explanation. Annals of Internal Medicine, 169(7), 467-473. https://doi. org/10.7326/M18-0850

Wilson, A., \& Beresford, P. (2000). Anti-oppressive practice: Emancipation or appropriation? British Journal of Social Work, 30(5), 553-573. https://doi.org/10.1093/bjsw/30.5.553

Yeung, P., \& Breheny, M. (2016). Using the capability approach to understand the determinants of subjective Well-being among community-dwelling older people in New Zealand. Age and Ageing, 45(2), 292-298. https://doi.org/10.1093/ageing/afw002

Open Access This chapter is licensed under the terms of the Creative Commons Attribution 4.0 International License (http://creativecommons.org/licenses/by/4.0/), which permits use, sharing, adaptation, distribution and reproduction in any medium or format, as long as you give appropriate credit to the original author(s) and the source, provide a link to the Creative Commons license and indicate if changes were made.

The images or other third party material in this chapter are included in the chapter's Creative Commons license, unless indicated otherwise in a credit line to the material. If material is not included in the chapter's Creative Commons license and your intended use is not permitted by statutory regulation or exceeds the permitted use, you will need to obtain permission directly from the copyright holder.

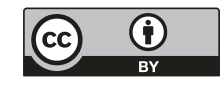

